CLINICAL STUDY

\title{
Interstitial IGF-I in exercising skeletal muscle in women
}

\author{
$\mathrm{U}_{\text {Berg }}^{1,2}$, T Gustafsson ${ }^{2,3}$, C J Sundberg ${ }^{2}$, L Kaijser ${ }^{3}$, C Carlsson-Skwirut ${ }^{1}$ and P Bang ${ }^{1,4}$ \\ ${ }^{1}$ Pediatric Endocrinology Unit, Department of Woman and Child Health, Karolinska Institute, Astrid Lindgren Children's Hospital, SE-171 76 Stockholm, \\ Sweden, ${ }^{2}$ Department of Physiology and Pharmacology, Karolinska Institute, SE-171 77 Stockholm, Sweden, ${ }^{3}$ Department of Laboratory Medicine, \\ Karolinska Institute, SE-141 86 Huddinge, Sweden and ${ }^{4}$ Department of Clinical Science, Intervention and Technology, Karolinska Institute, SE-141 86 \\ Stockholm, Sweden \\ (Correspondence should be addressed to U Berg; Email: ulrika.berg@ki.se)
}

\begin{abstract}
Objective: To study interstitial IGF-I concentrations in resting and exercising skeletal muscle in relation to the circulating components of the IGF-IGF binding protein (IGFBP) system.

Design and methods: Seven women performed endurance exercise with 1 leg (Ex-leg) for $1 \mathrm{~h}$. The resting leg (Rest-leg) served as a control. IGF-I was determined in microdialysate (MD) and was compared with veno-arterial ( $\mathrm{v}-\mathrm{a})$ concentrations of circulating IGF-IGFBP components.

Results: Median (range) basal MD-IGF-I was $0.87(0.4-1.5) \mu \mathrm{g} / \mathrm{l}$ or $0.4(0.2) \%$ of total-IGF-I (t-IGF-I) determined in arterial serum and in the same concentration range as free dissociable IGF-I (f-IGF-I). Rest-leg MD-IGF-I decreased, reaching significance after exercise. Ex-leg MD-IGF-I was unchanged during exercise and declined after exercise at the level of significance $(P=0.05)$. There was a release of f-IGF-I from the Ex-leg into the circulation at the end of and shortly after exercise. A small but significant increase in circulating IGFBP-1 was detected at the end of exercise and IGFBP-1 increased further after exercise. Although interleukin-6 (IL-6) has been associated with IGFBP-3 proteolysis, the circulating molecular forms of IGFBP-3 remained unchanged in spite of an IL-6 release from the muscle compartment.

Conclusions: Circulating IGFBP-1 is related to interstitial IGF-I in resting muscle although the temporal relationship may not be simple. Further studies should explore the role of local release of IGF-I and its impact on IGF-I activity during contraction.
\end{abstract}

European Journal of Endocrinology 157 427-435

\section{Introduction}

Insulin-like growth factor-I (IGF-I) is expressed in a large range of tissues. It exerts anabolic, differentiating, and metabolic effects. The major source of circulating IGF-I is the liver as confirmed by studies of liver-specific IGF-I knockout mice which have $20 \%$ of wild-type circulating total IGF-I (t-IGF-I) concentrations. Despite skeletal muscle insulin resistance and the development of diabetes in the liver-specific IGF-I knock-out (KO) mice, tissue anabolism (body weight and length) appears to be less affected by the deficiency of endocrine IGF-I, suggesting that locally produced IGF-I is important for anabolism (1). In fact, IGF-I is expressed in human skeletal muscle and involved in processes such as differentiation, hypertrophy, and angiogenesis. These remodeling effects of IGF-I and its metabolic effects are mediated by the IGF type 1 receptor (IGFIR). Functional inactivation of the IGF1R in skeletal muscle in mice causes muscle hypoplasia during the early postnatal stages. In contrast to the effect in wild-type mice, exercise fails to increase muscle fiber diameter and satellite cell proliferation in these mice (2). IGF-I and insulin are structurally homologous and they equipotently stimulate glucose uptake into skeletal muscle preparations ex vivo (3) and human muscle cell cultures in vitro (4). Transgenic mice lacking insulin receptors in skeletal muscle develop compensatory mechanisms to clear glucose (5), while mice with functional inactivation of both IGF1R and insulin receptors in skeletal muscle develop type 2 diabetes (6).

Altogether, the available data establish major biological effects of IGF-I and its importance for muscle tissue structural and functional adaptation to environmental demands. However, the reports on exercise-induced changes in skeletal muscle IGF-I mRNA and/or protein expression are rather sparse and, to some extent, contradictory (7-9). Moreover, the fact that the bioavailability of IGF-I is regulated by numerous factors other than changes in gene expression is somewhat overlooked.

IGF binding proteins (IGFBP-1-IGFBP-6) modulate the bioavailability of IGF-I in the circulation and tissues. In the circulation, most IGF-I is bound to IGFBP-3 and an acidlabile subunit in a large $150 \mathrm{kDa}$ ternary complex that reduces IGF-I bioavailability. IGF-I in the ternary complex is restricted to the circulation, while unbound IGF-I and possibly IGF-I in binary complexes have access to the extracellular fluid. Supraphysiological levels of IGFBP-1 inhibit the hypoglycemic effects of IGF-I in vivo (10). IGFBP-1 has previously been reported to increase in 
prolonged exercise (11). IGFBP-1 has been suggested to restrict IGF-I access to the tissues and prevent hypoglycemia, although the impact of IGFBP-1 on tissue concentrations of IGF-I has not previously been explored. Furthermore, increased serum proteolytic fragmentation of IGFBP-3 may increase IGF-I access to the tissues (12). Endocrine or locally produced IGF-I binds to IGFBPs in the extracellular fluid or to IGFBPs associated with the extracellular matrix or the cell surface (13). At the tissue level, IGFBP-1 inhibits IGF-induced glucose uptake in human skeletal muscle (14). Tissue-activated IGFBP proteases may further modulate IGF-I actions (15). Interleukin-6 (IL-6) increases the activity of proteases that degrade IGFBP-3 including matrix metalloproteinases $(16,17)$. Increased proteolytic degradation of IGFBP-3 has been detected in the circulation in human conditions of elevated IL- 6 and in transgenic mice overexpressing IL-6 (18). This suggests that IL-6 released from exercising skeletal muscle $(19,20)$ may locally increase IGFBP-3 proteolysis and IGF-I bioavailability.

The aim of the present study was to explore unbound IGF-I concentrations by microdialysis in skeletal muscle interstitial fluid. We used a one-legged knee extension exercise model (the contralateral leg served as a control) to induce profound acute changes in the local skeletal muscle tissue milieu. Interstitial IGF-I concentrations in the muscle and the circulating IGF-IGFBP system, including free dissociable IGF-I (f-IGF-I), were determined from arteriovenous ( $\mathrm{v}-\mathrm{a})$ differences over the exercising leg (Ex-leg). For the first time the (a-v) differences of IL-6 were determined in women.

\section{Subjects and methods}

\section{Subjects}

Seven healthy women were studied. Their mean (range) age, height, weight, and BMI were 28 years (23-39), $171 \mathrm{~cm}(165-177), 63 \mathrm{~kg}(54-72)$, and $21 \mathrm{~kg} / \mathrm{m}^{2}$ (20-23) respectively. They were not on any medication and they had regular menstrual cycles. The experiment was performed during the follicular phase of the cycle, confirmed by measurements of luteinizing hormone, follicle-stimulating hormone, estradiol, and progesterone on the day of the experiment (data not shown). Pregnancy was excluded by urine human chorionic gonadotropin (hCG) determination (TestPack Plus, Abbott). The study conformed to the standards set by the Declaration of Helsinki and was approved by the Karolinska Institute Ethics Committee (Number 546/03). Written informed consent was obtained from all subjects.

\section{Experimental protocol}

On two occasions before the experiment, each subject was familiarized with the experimental apparatus, a modified cycle ergometer built for one-legged knee extension exercise (at 60 r.p.m.) (21). On the second occasion (at least one week before the experiment), the maximal one-legged performance capacity was determined in a test where the workload was increased in $5 \mathrm{~W}$ increments every minute to fatigue. The mean maximal workload during one-legged exercise was 36 (4) W or $0.6(0.1) \mathrm{W} /$ $\mathrm{kg}$. Subjects were asked to avoid physical activity of moderate intensity or higher for $72 \mathrm{~h}$ before the day of the experiment. On that day subjects had a standardized breakfast at $0630 \mathrm{~h}$. The study was conducted between 0800 and $1500 \mathrm{~h}$ (Fig. 1). Microdialysis catheters were inserted in both vastus lateralis muscles $2.5 \mathrm{~h}$ before the onset of exercise, as described in detail below. Teflon catheters were inserted into the femoral artery of the later Ex-leg and both femoral veins. Patency of the catheters was maintained by intermittent flushing with a saline solution. The subjects rested in the supine position for $2 \mathrm{~h}$. Thereafter, they performed a one-legged knee extension exercise for $1 \mathrm{~h}$ in the sitting position with a workload corresponding to 60 (6)\% of the previously assessed maximal one-legged workload at 60 r.p.m. The absolute workload was 22 (3) W. The resting leg (Rest-leg) was allowed to move freely in order to avoid a workload

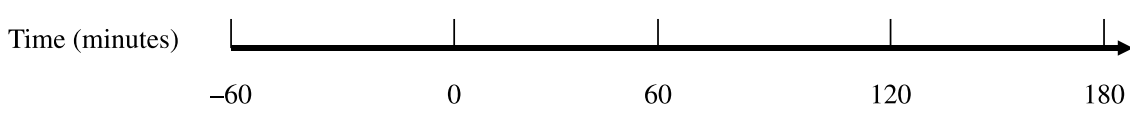

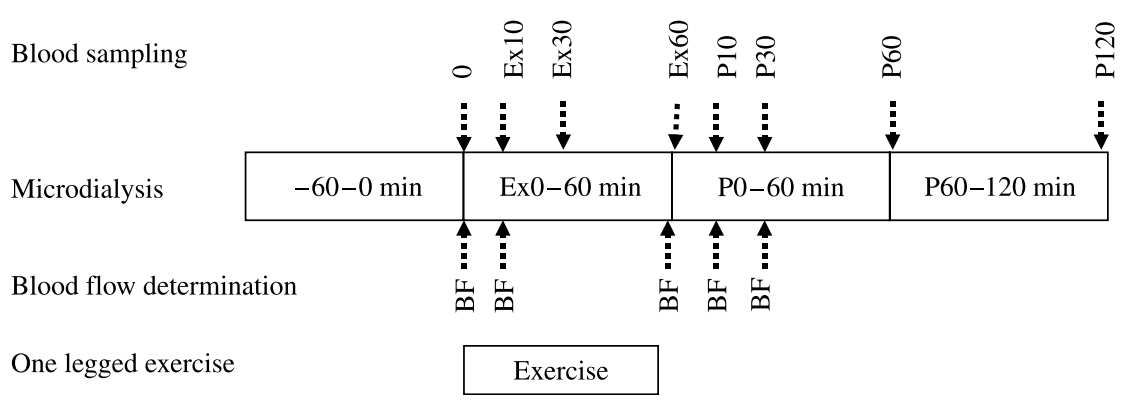

Figure 1 Experimental protocol. Seven women performed one-legged knee extension exercise for $1 \mathrm{~h}$ (0-60 $\mathrm{min})$. Microdialysate from the exercising (Ex-leg) and resting (Rest-leg) leg was collected during 60 -min periods. Blood sampling was performed in the femoral artery and vein of Ex-leg and the femoral vein of Rest-leg at eight time points (0 through $\mathrm{P} 120)$. Blood flow (BF) determinations in Ex-leg at five time points ( 0 through $P 30$ ) were completed in four subjects. 
associated with counteracting or balancing contractions while the Ex-leg was kicking. This resulted in simultaneous passive movements in the knee joint of the Rest-leg with an amplitude of approximately half that of the Ex-leg. The mean rate of perceived exertion, (RPE 6-20) as described in (22), was 15 (range 14-16). Finally, the subjects rested for $2 \mathrm{~h}$ in the supine position. Blood samples for hormone determinations were drawn from the femoral artery and vein of the Ex-leg before exercise (basal; time $=0)$, during exercise at $10(\mathrm{Ex} 10), 30(\mathrm{Ex} 30)$, and 60 (Ex60) min and at 10 (P10), 30 (P30), 60 (P60), and 120 (P120) min after exercise. Blood samples were kept on ice for $1 \mathrm{~h}$ to allow clotting before obtaining serum by centrifugation and storing at $-70{ }^{\circ} \mathrm{C}$. Blood for a B-glucose determination was collected in heparin-fluoride plasma vials and kept on ice until centrifugation and analysis. Blood samples from the femoral veins of both legs were obtained to assess blood flow using Cardiogreen infusion as described below.

\section{Hormones and biochemical markers}

IGF-I t-IGF-I was determined after acid/ethanol extraction of serum samples to exclude interference of IGFBPs (23) or directly in microdialysate (MD) by an IGF-I DELFIA originally described by Frystyk et al. (24) with a few modifications (25). The detection limit was $0.007 \mu \mathrm{g} / \mathrm{l}$ and the intra-assay $\mathrm{CV}$ for serum samples, including the extraction step, was $6.4 \%$. No interference of increasing concentrations of human albumin or ${ }^{14} \mathrm{C}$ inulin could be detected. Free IGF-I in serum was determined with a commercially available ELISA kit (DSL Inc., Webster, TX, USA).

IGFBP-I The total IGFBP-I serum levels were determined by a RIA described in (25) and modified from (26). The detection limit was $6 \mu \mathrm{g} / \mathrm{l}$ and the intra- and interassay CV was 5.6 and $11.8 \%$ respectively.

IGFBP-3 Immunoreactive total IGFBP-3 from the microdialysis in vitro and in vivo experiments was determined by ELISA, which is known to detect intact as well as fragmented IGFBP-3 (DSL Inc.; detection limit $0.73 \mu \mathrm{g} / \mathrm{l}$ ). IGFBP-3 fragmentation was determined in serum by western immunoblotting (WIB) using the enhanced chemiluminescence detection technique (27). The density of the bands was analyzed using the Image J computer program (National Institutes of Health, Bethesda, MD, USA). The serum IGFBP-3 in vivo fragmentation was expressed as a percentage of the major IGFBP-3 fragment (30 $\mathrm{kDa})$ relative to the total IGFBP-3 intensity (40-42 kDa $+30 \mathrm{kDa})$.

IL-6 IL-6 was determined with a high sensitivity ELISA kit (QuantiGlo, R\&D Systems, Abingdon, UK).
pH and $\boldsymbol{H b} \mathrm{pH}$ and $\mathrm{Hb}$ in venous blood from the Ex-leg were determined using an automatic spectrophotometric technique (ABL 520, Copenhagen, Denmark).

Glucose Plasma was kept on ice and analyzed on the day of the experiment. A hexokinase method was used to determine glucose concentrations (Gluco-quant, Roche Diagnostics $\mathrm{GmbH}$ ) in the artery to and the vein from the Ex-leg. The detection limit was $0.11 \mathrm{mM}$ $(0.02 \mathrm{~g} / \mathrm{l})$. The intra- and inter-assay $\mathrm{CV}$ was 1 and $3 \%$ respectively.

${ }^{14} \mathrm{C}$ inulin in $\boldsymbol{M D}{ }^{14} \mathrm{C}$ inulin reverse recovery (I-RR) was calculated from measurements of radioactivity in $10 \mu \mathrm{l}$ aliquots of collected MD compared with the perfusion fluid. After the addition of $5 \mathrm{ml}$ scintillation solution (Ready Safe, Beckman Coulter Inc., Fullerton, CA, USA), radioactivity was determined in a $\beta$-counter (Beckman LS 5000CE, Beckman Instruments, Fullerton, CA, USA).

\section{Microdialysis}

Probes, perfusion pumps, and perfusion fluid were all purchased from CMA Microdialysis (CMA, Solna, Sweden). Prior to the experiment, the microdialysis methodology was optimized and validated in vitro, as described later. The polyamide probe (CMA 60, 0.5-30 mm, cutoff $20 \mathrm{kDa}$ ) was perfused with a nonbuffered water solution containing $\mathrm{Na}^{+} 147 \mathrm{mM}, \mathrm{K}^{+} 4 \mathrm{mM}, \mathrm{Ca}^{2+} 2.3 \mathrm{mM}$, and $\mathrm{Cl}^{-} 156 \mathrm{mM}$, osmolality $290 \mathrm{mosm} / \mathrm{kg}$ and $\mathrm{pH}$ 6.0, provided by the manufacturer with an addition of $0.05 \%$ human serum albumin (HSA; Pharmacia). For assessment of changes in probe recovery of IGF-I $(7.5 \mathrm{kDa})$ related to muscle contractions and blood flow (28-32), ${ }^{14} \mathrm{C}$ inulin $(0.05 \mu \mathrm{Curie} / \mathrm{ml}$; $5 \mathrm{kDa}$; Amersham Biosciences) was chosen as an internal reference substance. The internal reference method is based on the concept that the ratio of the in vitro recovery of any two compounds is equal to the ratio of the recovery of the same two compounds in vivo. Inulin ( $5 \mathrm{kDa})$ has previously been used as a marker molecule for insulin $(5.8 \mathrm{kDa})$ due to similarity in molecular weight, lack of tissue binding, and metabolism of inulin and availability of a safe and stably labeled molecule (33-35). The perfusion flow rate was $2 \mu \mathrm{l} / \mathrm{min}$ (perfusion pump CMA 107). After inducing local anesthesia down to the muscle fascia (Mepivacainhydrochloride; Carbocain $10 \mathrm{mg} / \mathrm{ml}$, Astra Zeneca), two microdialysis catheters were inserted into the vastus lateralis muscle of each leg by insertion in a cranial direction, $45^{\circ}$ relative to the sagittal plane of the muscle. The distal end of the outlet tubing was cut off and inserted into a TreffLab polypropylene tube (Treff AG, Degersheim, Switzerland). To minimize the possible impact of skeletal muscle tissue response to the insertion trauma, microdialysis probes were inserted $2.5 \mathrm{~h}$ before onset of exercise and $1.5 \mathrm{~h}$ of equilibration was allowed before the collection of MD for IGF-I determinations. This approach has been taken in previous microdialysis studies $(28,36)$. 
MD was collected from the exercising (Ex-leg) and resting (Rest-leg) leg in the basal state ( -60 to $0 \mathrm{~min}$ ), during exercise (Ex0-Ex60) as well as after exercise (Ex60-P60) and (P60-P120) for the determination of IGF-I and ${ }^{14} \mathrm{C}$ inulin concentrations. The collecting tubes were weighed before and after collection and stored at $-70{ }^{\circ} \mathrm{C}$ until analysis.

In a series of in vitro experiments, microdialysis probes were submerged in a polyethylene tube containing an experimental 'interstitial fluid' consisting of a modified Krebs Henseleit solution with 0.05\% HSA (Pharmacia $\mathrm{AB})$ and $0.19(0.05) \mu \mathrm{g} / \mathrm{l}(0.0248(0.006) \mathrm{nM})$ of human recombinant IGF-I (kindly provided by Genentech Inc., South San Francisco, CA, USA) with or without IGFBP-3 (Upstate, NY, USA supplied by Chemicon Europe, Hampshire, UK). The composition of the perfusion fluid was the same as that in vivo described above (perfusion speed $2 \mu \mathrm{l} / \mathrm{min}$ ). Microdialysis of the 'interstitial fluid' was performed for up to $24 \mathrm{~h}$ at $37^{\circ} \mathrm{C}$ under gentle shaking. MD was collected at 1-h intervals for $4 \mathrm{~h}$ for IGF-I determination by DELFIA ( $n=4$ CMA 60 catheters). After the first $4 \mathrm{~h}$, a 10 molar excess of IGFBP- 3 was added to the 'interstitial fluid' in a final concentration of $10.6 \mu \mathrm{g} / \mathrm{l}(0.264 \mathrm{nM})$.

Addition of a 10 molar excess of IGFBP-3 decreased IGF-I in the MD by 48 (7)\% in accordance with the expected $50 \%$ calculated reduction in 'free IGF-I' using a $\mathrm{K}_{\mathrm{D}}$ of $0.24 \mathrm{nM}$ (12). Microdialysis of 'in vitro interstitial fluid' IGFBP-3 (GroPep, Adelaide, Australia) at $500 \mu \mathrm{g} / \mathrm{l}$, was not detectable in MD by SDS-PAGE and WIB after $16 \mathrm{~h}$ of collection (recovery of IGFBP-3 was $<1.6 \%$ ). We have previously reported (37) that larger IGFBP-3 fragments or IGF-IGFBP complexes (30-50 kDa) do not pass the microdialysis membrane.

Calculations The MD-IGF- $\mathrm{I}_{\text {absolute }}$ was corrected for IGF-I recovery in vivo according to the internal reference technique $(33,34)$. The reverse recovery of ${ }^{14} \mathrm{C}$ inulin $(\mathrm{I}-\mathrm{RR})_{\text {in vitro }}$ was calculated as the relative loss of ${ }^{14} \mathrm{C}$ inulin from the perfusion fluid $=\left({ }^{14} \mathrm{C}\right.$ inulin perfusion fluid $-{ }^{14} \mathrm{C}$ inulin $\left._{\text {dialysate }}\right) /{ }^{14} \mathrm{C}$ inulin $\left._{\text {perfusion fluid }}\right)$. The mean (I-RR) in vitro of ${ }^{14} \mathrm{C}$ inulin was $55(4) \%$ in the four catheters. The following formula was used for calculation of the IGF-I recovery ${ }_{\text {in vivo: }}$ (IGF-I recovery ${ }_{\text {in }}$ vitro $\times \mathrm{I}^{-\mathrm{RR}_{\text {in }} \text { vivo/ }}$ $\left.\mathrm{I}-\mathrm{RR}_{\text {in vitro }}\right)$. The mean relative recovery of IGF- $\mathrm{I}_{\text {in vitro }}=$

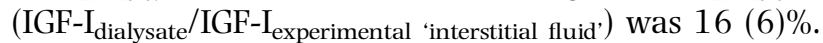
The mean intracatheter $\mathrm{CV}$ over time was $10 \%$. The actual measured interstitial IGF-I values (IGF-I $\mathrm{I}_{\text {absolute }}$ ) were corrected for IGF-I recovery $y_{\text {in vivo }}$ by the following formula: MD-IGF-I $=\left(\right.$ IGF-I $\left._{\text {absolute }}\right) \times\left(\right.$ IGF-I recovery $\left.y_{\text {in vivo }}\right)$.

\section{Leg blood flow and plasma flow}

Leg blood flow measurements before exercise (0), during exercise (Ex10, Ex30, and Ex60), and after exercise (P10 and P30) in Ex-leg were completed in four subjects. Leg blood flow was estimated according to the indicator-dilution technique (38). Leg plasma flow was calculated according to the following formula: leg blood flow $\times(100-E V F) / 100$. The EVF was determined exactly at the same time points as the leg blood flow determinations. The flux of substances over the leg was calculated according to the following formula: leg plasma flow $\times$ (venous plasma concentrations - arterial plasma concentrations).

\section{Statistical analysis}

Results are given as the mean (S.D.) if normally distributed; otherwise, as the median (range) unless otherwise stated. Variables with a normal distribution were compared by repeated measures ANOVA with time and artery/vein as dependent factors. Planned comparisons were used to locate differences corresponding to the significant interaction in the ANOVA model. The f-IGF-I was logtransformed to obtain normality prior to parametric statistical analysis (ANOVA) and then transformed back to the original scale. A nonparametric test (Friedman's ANOVA) was used if normality did not apply. Wilcoxon's matched pair test was performed to define where in time the difference was significant. Correlations were investigated with Spearman's nonparametric correlation test. Only individuals with complete data sets (data on every time point) were included in the statistical analyses. $P<0.05$ was considered significant.

\section{Results}

\section{IGF-I in MD-IGF-I}

IGF-I concentrations in (MD-IGF-I $\mathrm{I}_{\text {absolute }}$ ) were detectable in all subjects at all times. The MD-IGF-I absolute $_{\text {as }}$ well as IGF-I concentrations corrected for calculated IGF-I recovery (MD-IGF-I) are given in Table 1. Basal MD-IGF-I was $0.87(0.4-1.5) \mu \mathrm{g} / \mathrm{l}$ equal to $0.4(0.2) \%$ of t-IGF-I determined in arterial serum and in the same concentration range as f-IGF-I. Basal MD-IGF-I was higher in younger individuals $(R=-0.77, P=0.04)$.

Basal in vivo I-RR was 30 (7)\% in Ex-leg and 39 (3)\% in Rest-leg, markedly lower than 55 (4)\% in vitro. This difference resulted in a basal mean IGF-I recovery of 8 (1)\% in Ex-leg significantly lower than 11 (1)\% in Restleg. During exercise mean IGF-I recovery increased to $14(2) \%$ in the Ex-leg $(P<0.001$ compared with basal $)$ and returned back to basal levels during the first hour after exercise. Calculated IGF-I recovery did not change significantly over time in the Rest-leg $(P=0.08)$.

Rest-leg MD-IGF-I had already started to decline during exercise with a significant $58 \%$ decrease during the first hour after exercise $(0.54(0.4-0.8) \mu \mathrm{g} / \mathrm{l}$, $P=0.02$ ) as shown in Fig. 2. Ex-leg MD-IGF-I was unchanged during exercise and declined during the first hour after exercise at the limit of significance 
Table 1 Changes in microdialysate (MD) insulin-like growth factor-I (IGF-I) from skeletal muscle of seven healthy women performing onelegged aerobic exercise during $1 \mathrm{~h}$ (exercising (Ex) 0-Ex60).

\begin{tabular}{|c|c|c|c|c|}
\hline \multirow[b]{2}{*}{ Collection period } & \multicolumn{2}{|c|}{ MD-IGF-I $(\mu \mathrm{g} / \mathrm{l})$ absolute values } & \multicolumn{2}{|c|}{ MD-IGF-I $(\mu \mathrm{g} / \mathrm{l})$ values corrected for IGF-I recovery } \\
\hline & Ex-leg & Rest-leg & Ex-leg & Rest-leg \\
\hline $\begin{array}{l}(-60-0) \\
(\text { Ex0-Ex60) } \\
(\text { Ex60-P60) } \\
(P 60-P 120)\end{array}$ & $\begin{array}{l}0.07(0.02) \\
0.12(0.04)^{\mathrm{c}, \mathrm{e}} \\
0.07(0.04) \\
0.06(0.01)\end{array}$ & $\begin{array}{l}0.09(0.03)^{\mathrm{e}} \\
0.07(0.03) \\
0.06(0.02) \\
0.06(0.02)^{\mathrm{c}}\end{array}$ & $\begin{array}{l}0.87(0.4-1.5) \\
0.92(0.4-1.2) \\
0.58(0.4-1.0)^{\mathrm{a}}(n=6) \\
0.50(0.3-0.6)(n=4)\end{array}$ & $\begin{array}{l}0.77(0.4-1.2) \\
0.55(0.2-0.8) \\
0.54(0.4-0.8)^{\mathrm{b}}(n=5) \\
0.50(0.2-0.7)^{\mathrm{b}}(n=6)\end{array}$ \\
\hline
\end{tabular}

The mean (s.D.) MD-IGF-I absolute (absolute values) and median (range) MD-IGF-I (corrected for individual probe changes in IGF-I recovery), before, during, and after 60 -min one-legged exercise. ${ }^{\mathrm{a}} P=0.05,{ }^{\mathrm{b}} P<0.05,{ }^{\mathrm{c}} P<0.01,{ }^{\mathrm{d}} P<0.001$ versus basal $(-60-0)$ values in the same microdialysis probe and leg. ${ }^{\mathrm{e}} P<0.05$ Ex-leg versus Rest-leg. $n=7$ unless otherwise stated.

$(P=0.05)$. There was no correlation between the changes in I-RR and MD-IGF- $\mathrm{I}_{\text {absolute }}$ from basal levels to exercise in the individuals probes.

\section{t-IGF-I in serum}

Basal t-IGF-I was significantly lower in the vein than in the artery (Table 2). The basal uptake of t-IGF-I in the four individuals in whom blood flow was determined is shown in Table 2. During or after exercise no significant veno-arterial ( $\mathrm{v}-\mathrm{a})$ difference in t-IGF-I were observed. Venous t-IGF-I was increased by 11 (9)\% at Ex10 and returned to basal levels at Ex60. Arterial t-IGF-I did not change significantly during exercise but it was significantly decreased at P60.

\section{f-IGF-I in serum}

There was no significant ( $\mathrm{v}-\mathrm{a})$ difference in f-IGF-I in the basal state (Table 2). No significant changes in f-IGF-I were detected in the artery during or after exercise. Basal f-IGF-I in the vein was 0.38 (0.18$0.72) \%$ of venous t-IGF-I. At Ex10, there was a minor but significant decrease in venous f-IGF-I. At Ex60, venous f-IGF-I had returned to basal values. At Ex60 and P10, f-IGF-I was higher in the vein than in the artery in all the subjects. Table 2 shows (v-a) differences and the calculated individual net release of f-IGF-I. Among subjects with a calculated net f-IGF-I release over the Ex-leg at Ex60, the highest release was found in those with the highest MD-IGF-I (Ex-leg) during exercise.

\section{IGFBP-1 in serum}

The arterial IGFBP-1 (Fig. 3) was increased at Ex60 $(P=0.04)$, increased further at $P 60$, and remained significantly elevated at P120 $(P=0.007)$. The changes in IGFBP-1 and MD-IGF-I in the Ex-leg and/or Rest-leg did not correlate. However, the relative change in the Rest-leg MD-IGF-I $\mathrm{I}_{\text {absolute }}$ during exercise was inversely correlated with the relative change in arterial IGFBP-1 $(R=-0.8 ; P=0.02)$.

\section{IGFBP-3 in serum}

Basal total IGFBP-3 was 4625 (474) $\mu \mathrm{g} / \mathrm{l}$. There was no significant change in total IGFBP-3 fragmentation with time in the artery or the vein (data not shown). IGFBP-3 WIB detected intact glycosylated IGFBP-3 (doublet at 40-43 kDa) and a major IGFBP-3 proteolytic fragment (at $30 \mathrm{kDa}$ ) in both the artery and the vein. The size of the major IGFBP-3 fragment was similar to that found in pregnancy serum.

\section{IL-6 in serum}

IL-6 increased during exercise (Table 2), reaching significance in the artery at $\operatorname{Ex} 60(P=0.008)$, and in the vein at $\mathrm{P} 10(P=0.008)$. Basal IL-6 was significantly higher in the vein than in the artery $(P=0.007)$. The (v-a) difference was significantly increased from basal values at P10 $(P=0.02)$ and remained elevated at P60 $(P=0.004)$. The net release of IL-6 was calculated in the four subjects where blood flow could be determined (Table 2).

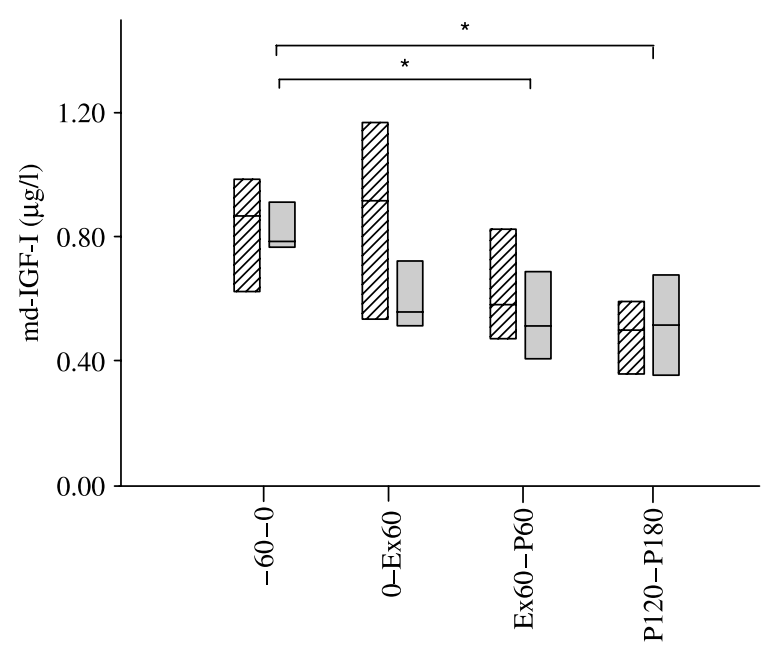

Figure 2 The MD-IGF-I concentrations in the Ex-leg (hatched bars) and Rest-leg (grey bars) before (-60-0), during (0-Ex60), and after exercise (Ex60-P60) and (P60-P120). Boxes represents median with the 5 th and 95 th percentiles. ${ }^{*}=P<0.05$ versus basal values $(-60-0)$. 
Table 2 Total IGF-I (t-IGF-I), free dissociable IGF-I (f-IGF-I) and interleukin-6 (IL-6) in the artery (a) and the vein (v) of the exercising (Ex) leg in seven women performing one-legged aerobic exercise.

\begin{tabular}{|c|c|c|c|c|}
\hline $\begin{array}{l}\text { Time } \\
\text { point }\end{array}$ & & t-IGF-I $(\mu \mathrm{g} / \mathrm{l})$ & f-IGF-I $(\mu \mathrm{g} / \mathrm{l})$ & IL-6 (ng/l) \\
\hline 0 & $\begin{array}{l}\text { a, v } \\
\text { v-a } \\
\text { Release/uptake }\end{array}$ & $\begin{array}{l}230(42), 202(38)^{\mathrm{e}} \\
-28.0(19) \\
-18 / 0.7 /-10 /-6.0\end{array}$ & $\begin{array}{l}0.68(0.39,1.19), 0.74(0.42,1.27) \\
0.05(-0.13,0.23) \\
0.14 / 0.0 / 0.0 / 0.0\end{array}$ & $\begin{array}{l}4.0(3.0-6.1), 6.1(3.6-9.1)^{\mathrm{e}} \\
1.0(0.5-3.1) \\
0.2 / 0.2 / 0.2 / 0.6\end{array}$ \\
\hline Ex10 & $\begin{array}{l}\text { a, v } \\
\text { v-a } \\
\text { Release/uptake }\end{array}$ & $\begin{array}{l}227(40), 227(50)^{\mathrm{a}} \\
-0.4(11) \\
10 /-10 / 21 /-16\end{array}$ & $\begin{array}{l}0.58(0.30,1.13), 0.66(0.41,1.06)^{a} \\
-0.06(-0.47,0.34) \\
0.37 /-^{2} / 0.05 /-0.01\end{array}$ & $\begin{array}{l}\text { N.D., N.D. } \\
\text { N.D. } \\
\text { N.D. }\end{array}$ \\
\hline Ex30 & $\begin{array}{l}\text { a, v } \\
\text { v-a } \\
\text { Release/uptake }{ }^{1}\end{array}$ & $\begin{array}{l}231(56), 239(49)^{\mathrm{c}} \\
8.1(14) \\
\text { N.D. }\end{array}$ & $\begin{array}{l}0.60(0.33,1.09), 0.68(0.40,1.14) \\
0.05(-0.10,0.20) \\
\text { N.D. }\end{array}$ & $\begin{array}{l}6.1(4.1-27.8), 7.9(4.8-29.3) \\
0.3(0.0-2.6) \\
\text { N.D. }\end{array}$ \\
\hline Ex60 & $\begin{array}{l}\text { a, v } \\
\text { v-a } \\
\text { Release/uptake }\end{array}$ & $\begin{array}{l}228(51), 215(43) \\
-12.4(22) \\
5.5 /-8.1 /-117 /-20\end{array}$ & $\begin{array}{l}0.69(0.40,1.22), 0.78(0.48,1.27)^{\mathrm{e}} \\
0.12(0.03,0.21) \\
0.07 /-^{2} / 0.25 / 0.15\end{array}$ & $\begin{array}{l}6.2(4.1-27.7)^{\mathrm{b}}, 8.0(4.8-29.3)^{\mathrm{f}} \\
1.6(0.7-2.3) \\
1.4,1.1,3.3,2.4\end{array}$ \\
\hline P10 & $\begin{array}{l}\text { a, v } \\
\text { V-a } \\
\text { Release/uptake }\end{array}$ & $\begin{array}{l}224(60), 221(55) \\
-2.7(16) \\
-16 / 1.0 / 4.8 / 0.5\end{array}$ & $\begin{array}{l}0.66(0.41,1.05), 0.74(0.44,1.23)^{\dagger} \\
0.10(0.01,0.19) \\
0.15 /-0.03 / 0.03 / 0.03\end{array}$ & $\begin{array}{l}6.9(4.1-27.1)^{d}, 14.2(7.9-44.5)^{c, f} \\
5.2(3.8-17.3)^{g} \\
3.4 / 1.1 / 0.7 / 3.9\end{array}$ \\
\hline P60 & $\begin{array}{l}\text { a, v } \\
\text { v-a } \\
\text { Release/uptake }{ }^{1}\end{array}$ & $\begin{array}{l}197(55)^{\mathrm{C}}, 203(48) \\
5.6(12) \\
\text { N.D. }\end{array}$ & $\begin{array}{l}0.54(0.32,0.92), 0.51(0.29,0.93)^{\mathrm{a}} \\
0.01(-0.16,0.13) \\
\text { N.D. }\end{array}$ & $\begin{array}{l}5.7(3.6-16.4)^{\mathrm{b}}, 11.0(8.5-35.7)^{\mathrm{b}, \mathrm{f}} \\
5.8(2.5-19.3)^{\mathrm{h}} \\
\text { N.D. }\end{array}$ \\
\hline
\end{tabular}

The t-IGF-I is given as the mean (S.D.) and the log-transformed f-IGF-I is transformed back and given as the mean (mean - S.D. and mean + S.D.). IL- 6 is given as median (range); n.d., not determined. ${ }^{\mathrm{a}} P<0.05,{ }^{\mathrm{b}} P<0.01,{ }^{\mathrm{c}} P<0.001,{ }^{\mathrm{d}} P<0.001$ versus basal (time $=0$ ) values in the same catheter (artery/vein). ${ }^{\mathrm{e}} P<0.05,{ }^{\mathrm{f}} P<0.001$ vein vs. artery. ${ }^{\mathrm{g}} P<0.05,{ }^{\mathrm{h}} P<0.01$ versus basal (v-a) difference.

${ }^{1}$ Blood flow was calculated in four subjects. Therefore, fluxes of t-IGF-I ( $\left.\mu \mathrm{g} / \mathrm{min}\right)$, f-IGF-I ( $\left.\mu \mathrm{g} / \mathrm{min}\right)$, and IL-6 (ng/min) are given as four individual values. Release is indicated by $(+)$ and uptake as $(-) .{ }^{2}$ Missing value

\section{Glucose in plasma (P-glucose)}

Arterial P-glucose decreased from a basal value of 5.4 (0.4) to $4.9(0.5) \mathrm{mmol} / \mathrm{l}$ at $\operatorname{Ex} 30(P=0.0001)$ and remained decreased at $\mathrm{P} 120(P=0.0001)$. Basal glucose uptake was $0.05(0.01-0.20) \mathrm{mmol} / \mathrm{min}(n=4)$ and increased to $0.18(0.08-0.31) \mathrm{mmol} / \mathrm{min}$ at Ex60 $(P=0.001 ; n=4)$. The peak mean glucose uptake $(\mathrm{P} 10)$ was $0.21(0.17-0.51) \mathrm{mmol} / \mathrm{min}(P=0.09 ; n=4)$. No correlation between glucose uptake and MD-IGF-I in the Ex-leg could be detected at any time point.

\section{Blood flow and $\mathrm{pH}$}

The Ex-leg venous $\mathrm{pH}$ was decreased from a basal value of $7.36(7.32-7.37)$ to $7.28(7.24-7.29)$ at $\operatorname{Ex} 10$ $(P=0.001)$ and $7.31(7.29-7.32)$ at $\operatorname{Ex} 30(P=0.01)$, and then returned to basal values at Ex60. Basal $\mathrm{Hb}$ was 133 (130-141) g/l and did not change significantly during exercise. At P30, $\mathrm{Hb}$ was decreased by 6 (3)\% $(P=0.03)$. The mean increase in blood flow in the Ex-leg in the four subjects for whom measurements were complete was almost fourfold $(0.45(0.39-0.58)$ $\mathrm{l} / \mathrm{min}$ versus $2.08(1.7-2.7) \mathrm{l} / \mathrm{min}$ at $\mathrm{Ex} 10, P=0.007)$ and remained significantly elevated during exercise. Blood flow returned to basal values at P10.

\section{Discussion}

For the first time, we have assessed interstitial IGF-I concentrations by determining IGF-I concentrations in MD with correction for probe recovery in resting and exercising human skeletal muscle in women. At rest, interstitial IGF-I in muscle was estimated to be in the same concentration range as f-IGF-I in serum. Rest-leg MD-IGFI decreased after exercise concomitantly with an increase in circulating IGFBP-1, offering the first direct evidence that IGFBP-1 may alter peripheral tissue levels although the temporal relationship may not be simple. After correction for probe recovery, the increase in Ex-leg MD-IGF-I during exercise was attenuated and did not reach significance. Thereafter, Ex-leg MD-IGF-I decreased with an apparent delay compared with Rest-leg. This may suggest that in Ex-leg, exercise-induced mobilization of

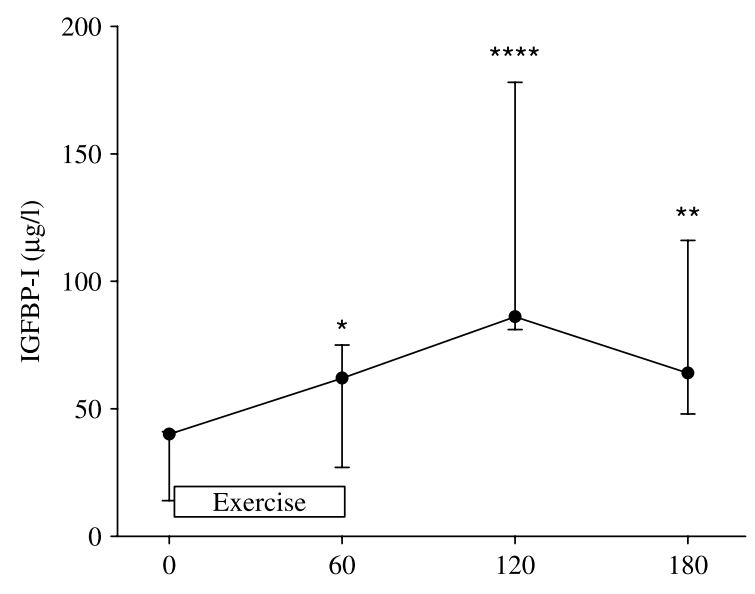

Figure 3 Circulating arterial IGFBP-1 $(\mu \mathrm{g} / \mathrm{l})$ before, during, and after $60 \mathrm{~min}$ of one-legged exercise $(n=7)$. Values are given as median (25th-75th percentiles). ${ }^{*}=P<0.05,{ }^{* *}=P<0.01,{ }^{* \star \star *}=P<0.0001$ versus basal (time $=0$ ). 
local tissue-bound IGF-I stores compensates for the impact of increased circulating IGFBP-1 on local IGF-I.

In this study, basal skeletal muscle MD-IGF-I levels, calculated by the internal reference technique for in vivo probe recovery, were in the same range as f-IGF-I in serum. Two other approaches have been reported to assess interstitial IGF-I in resting muscle. When skeletal muscle extracellular fluid was collected with a $3000 \mathrm{kDa}$ probe $(39,40)$, t-IGF-I was reported to be tenfold higher than MD-IGF-I in the present study. The impact of IGFBPs collected along with IGF-I was not assessed by these authors. In the other approach, MD from a $60 \mathrm{kDa}$ probe, also likely to contain IGFBPs was analyzed using a free IGF-I kit (41). MD-free IGF-I was tenfold higher than f-IGFI in serum, suggesting the presence of a steep gradient of unbound IGF-I from the muscle to the circulation. Such a gradient would imply that endocrine IGF-I does not contribute to local tissue levels. This conclusion is not in accordance with the marked effects of endocrine IGF-I on glucose metabolism in mice (1) and humans (42). Our findings of MD-IGF-I in the same range as f-IGF-I in serum, support that endocrine IGF-I may have impact on resting skeletal muscle and whole body glucose homeostasis as previously reported $(1,42,43)$. We further observed a significant uptake of t-IGF-I over skeletal muscle in the basal state, suggesting that IGF-I is cleared in the resting muscle possibly following stimulation of the IGF1R.

Rest-leg MD-IGF-I decreased, reaching significance after exercise. Circulating IGFBP-1 was already significantly increased at the end of exercise but increased further after exercise. If there is a temporal relationship between circulating IGFBP-1 and local IGF-I bioavailability, it may not be as simple as first assumed. Changes in IGFBP-1 in serum are to a large part determined by hepatic production but changes in IGFBP-1 transport to the tissues may contribute. Consequently, tissue changes in IGFBP-1 may not be completely reflected by the changes in circulating IGFBP-1. The exact mechanism by which circulating IGFBP-1 affects tissue IGF-I levels should be further explored in a less-complex study model.

In Ex-leg, the decrease in MD-IGF-I appeared to be delayed as a result of an increase in MD-IGF- $\mathrm{I}_{\text {absolute }}$ during exercise in accordance with our previous findings in men (44). In that study, the microdialysis methodology was not optimized and most of the basal levels were below the detection limit. The MD-IGF-I in Ex-leg was elevated during and after exercise. However, MD-IGF-I was not corrected for probe recovery and Rest-leg MD-IGF-I concentrations were not determined. It is known that muscle contraction induces changes in probe recovery (45). In the present study, we attempted to control for probe recovery by calculating IGF-I recovery from the reverse recovery of ${ }^{14} \mathrm{C}$ inulin using the internal reference method $(33,34)$. In previous exercise studies, reference molecules with molecular weights similar to $(29,36)$ or different from $(31,32$, 40) the substance of interest have been used.
Although the higher molecular weight of IGF-I compared with inulin resulted in a lower recovery than we expected, this result is not in conflict with the principle of the internal reference method (34). We found a significant difference between basal IGFI recovery in the resting and Ex-leg. It is possible that this may reflect variability in recovery between probes within the same batch. Considering the limited number of subjects, this may alternatively represent a type 1 error. Further evaluation of the validity of the I-RR is required to resolve this issue.

The lack of correlation between the changes in I-RR and MD-IGF- $\mathrm{I}_{\text {absolute }}$ from rest to exercise in this study suggests that the increase in probe recovery does not fully account for the increase in MD-IGF- $\mathrm{I}_{\text {absolute }}$. When

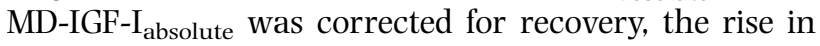
Ex-leg MD-IGF-I was attenuated and did not reach significance. It is likely that I-RR is influenced by the increase in Ex-leg blood flow. If so, corrected MD-IGF-I values may underestimate local bioavailable IGF-I in the muscle resulting from the increased IGF-I flux to the muscle. In addition, the difference in MD-IGF-I response to exercise in Ex-leg versus Rest-leg may be explained by local exercise-induced mobilization of tissue-bound IGF-I stores. This view is supported by the net release of Ex-leg f-IGF-I at the end of exercise, suggesting that the source of IGF-I is the muscle itself. The difference was observed already during the first hour after exercise which favors release of local stores of IGF-I rather than de novo synthesis. A local release would also explain that the impact of increased circulating IGFBP-1 on local IGF-I appears to be less pronounced in Ex-leg during the first hour after exercise. A release of IGF-I from local stores may be induced by proteolytic cleavage of IGFBP$3(46,47)$. IGFBP-3 proteolysis is associated with increased IL-6 (16, 17). For the first time, we demonstrate that the net release of IL- 6 from skeletal muscle is increased during and after exercise in women and confirms previous reports in men (48). The absence of an increased IGFBP-3 proteolysis in serum does not exclude the possibility that IGFBP proteases are activated locally. The decrease in $\mathrm{pH}$ observed in the blood from Ex-leg reflects a decrease in $\mathrm{pH}$ in skeletal muscle tissue that theoretically may decrease IGF-I binding to the IGFBPs. Furthermore, an IGF-I protease with a $\mathrm{pH}$ optimum around 6.0 is known to cleave IGF-I to des - (1-3) IGF-I resulting in a reduced binding to IGFBPs (49). Further investigation of IGFBP protease activity in muscle interstitial fluid is warranted, but this will require probes with a larger pore size.

In the circulation, changes in IGF-I bioavailability associated with IGFBP-1 has previously been assessed by changes in f-IGF-I (50). The present study is the first to report ( $\mathrm{v}-\mathrm{a})$ differences of $\mathrm{f}-\mathrm{IGF}-\mathrm{I}$ in exercising human skeletal muscle. In the vein, f-IGF-I was higher at the end of exercise and shortly thereafter, indicating a release of unbound IGF-I into the circulation. This finding supports the hypothesis that local exercise-induced mobilization of 
tissue-bound IGF-I stores affects local levels of IGF-I in the exercising muscle. In previous exercise studies, circulating f-IGF-I has been determined in an antecubital vein and has been reported to be increased (51) or unchanged (52). In the present study, the quantity of f-IGF-I released was not sufficient to be detectable in the large pool of t-IGF-I in the circulation.

This study of interstitial IGF-I protein concentrations during and shortly after a single bout of aerobic exercise of moderate duration indicates rapid changes in IGF-I concentrations. Since IGF-I protein synthesis and release induced by changes in IGF-I mRNA are likely to take hours to peak (53), non-transcriptional regulation such as local changes in IGF-I bioavailability is a likely mechanism. The role of muscle interstitial IGF-I during and after aerobic exercise needs to be further explored. Single aerobic exercise bouts and/or training result in increased vascularization, skeletal tissue remodeling (such as fiber type transformation), and a sustained increase in glucose uptake after exercise (54). Changes in interstitial muscle IGF-I may potentially be important for these processes.

\section{Acknowledgements}

This work was supported by the Swedish National Center for Research in Sports, the Samariten Foundation, the Wera Ekstrom Foundation, the Frimurare Barnhuset Foundation in Stockholm, the Swedish Society of Medicine, the Society for Child Care, the H R H Crown Princess Lovisa Society for Medicine, and the Swedish Research Council. IGF-I was kindly provided by Paul Fielder, Genentech Inc., South San Francisco, CA, USA. The catching IGF-I monoclonal antibody was kindly provided by Novo Nordisk, Bagsvaerd, Denmark. Gittan Jonas, Monica Borggren, Gunilla Hedin, and Henning Wallerstedt assisted during the experiments. Prof. Urban Ungerstedt and Dr Michel Goiny (Department of Physiology and Pharmacology, Karolinska Institutet, Stockholm) gave valuable inputs.

\section{References}

1 Yakar S, Liu JL, Fernandez AM, Wu Y, Schally AV, Frystyk J, Chernausek SD, Mejia W \& Le Roith D. Liver-specific igf-1 gene deletion leads to muscle insulin insensitivity. Diabetes 200150 1110-1118.

2 Fernandez AM, Dupont J, Farrar RP, Lee S, Stannard B \& Le Roith D. Muscle-specific inactivation of the IGF-I receptor induces compensatory hyperplasia in skeletal muscle. Journal of Clinical Investigation 2002109 347-355.

3 Dohm GL, Elton CW, Raju MS, Mooney ND, DiMarchi R, Pories WJ, Flickinger EG, Atkinson SM Jr \& Caro JF. IGF-I - stimulated glucose transport in human skeletal muscle and IGF-I resistance in obesity and NIDDM. Diabetes 199039 1028-1032.

4 Ciaraldi TP, Carter L, Seipke G, Mudaliar S \& Henry RR. Effects of the long-acting insulin analog insulin glargine on cultured human skeletal muscle cells: comparisons to insulin and IGF-I. Journal of Clinical Endocrinology and Metabolism 200186 5838-5847.
5 Bruning JC, Michael MD, Winnay JN, Hayashi T, Horsch D, Accili D, Goodyear LJ \& Kahn CR. A muscle-specific insulin receptor knockout exhibits features of the metabolic syndrome of NIDDM without altering glucose tolerance. Molecular Cell 19982 559-569.

6 Fernandez AM, Kim JK, Yakar S, Dupont J, Hernandez-Sanchez C, Castle AL, Filmore J, Shulman GI \& Le Roith D. Functional inactivation of the IGF-I and insulin receptors in skeletal muscle causes type 2 diabetes. Genes and Development 200115 1926-1934.

7 Hellsten Y, Hansson HA, Johnson L, Frandsen U \& Sjodin B. Increased expression of xanthine oxidase and insulin-like growth factor I (IGF-I) immunoreactivity in skeletal muscle after strenuous exercise in humans. Acta Physiologica Scandinavica 1996157 191-197.

8 Bickel CS, Slade J, Mahoney E, Haddad F, Dudley GA \& Adams GR. Time course of molecular responses of human skeletal muscle to acute bouts of resistance exercise. Journal of Applied Physiology $200598482-488$.

9 Haddad F, Baldwin KM \& Tesch PA. Pretranslational markers of contractile protein expression in human skeletal muscle: effect of limb unloading plus resistance exercise. Journal of Applied Physiology 200598 46-52.

10 Lewitt MS, Denyer GS, Cooney GJ \& Baxter RC. Insulin-like growth factor-binding protein-1 modulates blood glucose levels. Endocrinology $19911292254-2256$.

11 Suikkari AM, Sane T, Seppala M, Yki-Jarvinen H, Karonen SL \& Koivisto VA. Prolonged exercise increases serum insulin-like growth factor-binding protein concentrations. Journal of Clinical Endocrinology and Metabolism 198968 141-144.

12 Bang P, Ahlsen M, Berg U \& Carlsson-Skwirut C. Free insulin-like growth factor I: are we hunting a ghost? Hormone Research 2001 55 (Suppl 2) 84-93.

13 Jones JI \& Clemmons DR. Insulin-like growth factors and their binding proteins: biological actions. Endocrine Reviews 199516 3-34.

14 Zierath JR, Bang P, Galuska D, Hall K \& Wallberg-Henriksson H. Insulin-like growth factor II stimulates glucose transport in human skeletal muscle. FEBS Letters 1992307 379-382.

15 Campbell PG, Novak JF, Yanosick TB \& McMaster JH. Involvement of the plasmin system in dissociation of the insulin-like growth factorbinding protein complex. Endocrinology 1992130 1401-1412.

16 Kossakowska AE, Edwards DR, Prusinkiewicz C, Zhang MC, Guo D, Urbanski SJ, Grogan T, Marquez LA \& JanowskaWieczorek A. Interleukin-6 regulation of matrix metalloproteinase (MMP-2 and MMP-9) and tissue inhibitor of metalloproteinase (TIMP-1) expression in malignant non-Hodgkin's lymphomas. Blood 199994 2080-2089.

17 Janowska-Wieczorek A, Marquez LA, Nabholtz JM, Cabuhat ML, Montano J, Chang H, Rozmus J, Russell JA, Edwards DR \& Turner AR. Growth factors and cytokines upregulate gelatinase expression in bone marrow $\mathrm{CD} 34(+)$ cells and their transmigration through reconstituted basement membrane. Blood 199993 3379-3390.

18 De Benedetti F, Meazza C, Oliveri M, Pignatti P, Vivarelli M, Alonzi T, Fattori E, Garrone S, Barreca A \& Martini A. Effect of IL-6 on IGF binding protein-3: a study in IL-6 transgenic mice and in patients with systemic juvenile idiopathic arthritis. Endocrinology $20011424818-4826$.

19 Steensberg A, Keller C, Starkie RL, Osada T, Febbraio MA \& Pedersen BK. IL-6 and TNF-alpha expression in, and release from, contracting human skeletal muscle. American Journal of Physiology 2002283 E1272-E1278.

20 Steensberg A, van Hall G, Osada T, Sacchetti M, Saltin B \& Klarlund Pedersen B. Production of interleukin-6 in contracting human skeletal muscles can account for the exercise-induced increase in plasma interleukin-6. Journal of Physiology $2000 \mathbf{5 2 9}$ 237-242.

21 Andersen P, Adams RP, Sjogaard G, Thorboe A \& Saltin B. Dynamic knee extension as model for study of isolated exercising muscle in humans. Journal of Applied Physiology 198559 1647-1653. 
22 Borg G. Perceived exertion as an indicator of somatic stress. Scandinavian Journal of Rehabilitation Medicine 19702 92-98.

23 Bang P, Eriksson U, Sara V, Wivall IL \& Hall K. Comparison of acid ethanol extraction and acid gel filtration prior to IGF-I and IGF-II radioimmunoassays: improvement of determinations in acid ethanol extracts by the use of truncated IGF-I as radioligand. Acta Endocrinologica 1991124 620-629.

24 Frystyk J, Ivarsen P, Stoving RK, Dall R, Bek T, Hagen C \& Orskov H. Determination of free insulin-like growth factor-I in human serum: comparison of ultrafiltration and direct immunoradiometric assay. Growth Hormone and IGF Research 2001 11 117-127.

25 Pihl S, Carlsson-Skwirut C, Berg U, Ekstrom K \& Bang P. Acute interleukin-6 infusion increases IGFBP-1 but has no short-term effect on IGFBP-3 proteolysis in healthy men. Hormone Research 200665 177-184.

26 Westwood M, Gibson JM, Davies AJ, Young RJ \& White A. The phosphorylation pattern of insulin-like growth factor-binding protein-1 in normal plasma is different from that in amniotic fluid and changes during pregnancy. Journal of Clinical Endocrinology and Metabolism 1994 79 1735-1741.

27 Hossenlopp P, Segovia B, Lassarre C, Roghani M, Bredon M \& Binoux M. Evidence of enzymatic degradation of insulin-like growth factor-binding proteins in the $150 \mathrm{~K}$ complex during pregnancy. Journal of Clinical Endocrinology and Metabolism 1990 71 797-805.

28 Hoffner L, Nielsen JJ, Langberg H \& Hellsten Y. Exercise but not prostanoids enhance levels of vascular endothelial growth factor and other proliferative agents in human skeletal muscle interstitium. Journal of Physiology 2003 550 217-225.

29 Juel C, Pilegaard H, Nielsen JJ \& Bangsbo J. Interstitial $\mathrm{K}(+)$ in human skeletal muscle during and after dynamic graded exercise determined by microdialysis. American Journal of Physiology 2000 278 R400-R406.

30 Langberg H, Skovgaard D, Karamouzis M, Bulow J \& Kjaer M. Metabolism and inflammatory mediators in the peritendinous space measured by microdialysis during intermittent isometric exercise in humans. Journal of Physiology 1999515 919-927.

31 Langberg H, Olesen JL, Gemmer C \& Kjaer M. Substantial elevation of interleukin-6 concentration in peritendinous tissue, in contrast to muscle, following prolonged exercise in humans. Journal of Physiology $2002 \mathbf{5 4 2} 985-990$.

32 Trappe T, Raue U, Williams R, Carrithers J \& Hickner R. Effects of age and resistance exercise on skeletal muscle interstitial prostaglandin $\mathrm{F}(2 \alpha)$. Prostaglandins, Leukotrienes, and Essential Fatty Acids 2006 74 175-181.

33 Lonnroth $\mathrm{P} \&$ S Strindberg L. Validation of the internal reference technique' for calibrating microdialysis catheters in situ. Acta Physiologica Scandinavica 1995153 375-380.

34 Strindberg L \& Lonnroth P. Validation of an endogenous reference technique for the calibration of microdialysis catheters. Scandinavian Journal of Clinical and Laboratory Investigation 200060 205-211.

35 Sjostrand M, Holmang A \& Lonnroth P. Measurement of interstitial insulin in human muscle. American Journal of Physiology 1999276 E151-E154.

36 Frandsen U, Bangsbo J, Langberg H, Saltin B \& Hellsten Y. Inhibition of nitric oxide synthesis by systemic N(G)-monomethylL-arginine administration in humans: effects on interstitial adenosine, prostacyclin and potassium concentrations in resting and contracting skeletal muscle. Journal of Vascular Research 2000 37 297-302.

37 Berg U, Gustafsson T, Sundberg CJ, Carlsson-Skwirut C, Hall K, Jakeman P \& Bang P. Local changes in the insulin-like growth factor system in human skeletal muscle assessed by microdialysis and arterio-venous differences technique. Growth Hormone and IGF Research $200616217-223$.

38 Wahren J \& Jorfeldt L. Determination of leg blood flow during exercise in man: an indicator-dilution technique based on femoral venous dye infusion. Clinical Science and Molecular Medicine 1973 42 (Suppl) 135-146.
39 Miller BF, Olesen JL, Hansen M, Dossing S, Crameri RM, Welling RJ, Langberg $H$, Flyvbjerg A, Kjaer M, Babraj JA, Smith K \& Rennie MJ. Coordinated collagen and muscle protein synthesis in human patella tendon and quadriceps muscle after exercise. Journal of Physiology $2005 \mathbf{5 6 7} 1021-1033$.

40 Olesen JL, Heinemeier KM, Gemmer C, Kjaer M, Flyvbjerg A \& Langberg H. Exercise dependent IGF-I, IGFBPs and type-I collagen changes in human peritendinous connective tissue determined by microdialysis. Journal of Applied Physiology 2007102 214-220.

41 Desvigne N, Barthelemy JC, Frere D, Gay-Montchamp JP \& Costes F. Microdialysis of insulin-like growth factor-I in human muscle. European Journal of Applied Physiology 200594 216-219.

42 Saukkonen T, Amin R, Williams RM, Fox C, Yuen KC, White MA, Umpleby AM, Acerini CL \& Dunger DB. Dose-dependent effects of recombinant human insulin-like growth factor (IGF)-I/IGF binding protein-3 complex on overnight growth hormone secretion and insulin sensitivity in type 1 diabetes. Journal of Clinical Endocrinology and Metabolism 200489 4634-4641.

43 Camacho-Hubner C, Woods KA, Miraki-Moud F, Clark A \& Savage MO. Insulin-like growth factor-I deficiency caused by a partial deletion of the IGF-I gene: effects of rhIGF-I therapy. Growth Hormone and IGF Research 19999 (Suppl B) 47-51 (discussion 51-42).

44 Berg U, Gustafsson T, Sundberg CJ, Carlsson-Skwirut C, Hall K, Jakeman P \& Bang P. Local changes in the insulin-like growth factor system in human skeletal muscle assessed by microdialysis and arterio-venous differences technique. Growth Hormone and IGF Research $200616217-223$.

45 Radegran G \& Saltin B. Muscle blood flow at onset of dynamic exercise in humans. American Journal of Physiology $1998 \mathbf{2 7 4}$ H314-H322.

46 Jones JI, Doerr ME \& Clemmons DR. Cell migration: interactions among integrins, IGFs and IGFBPs. Progress in Growth Factor Research $19956319-327$.

47 Oh Y, Muller HL, Pham H \& Rosenfeld RG. Demonstration of receptors for insulin-like growth factor binding protein-3 on Hs578T human breast cancer cells. Journal of Biological Chemistry $199326826045-26048$.

48 Pedersen BK, Steensberg A, Fischer C, Keller C, Keller P, Plomgaard P, Febbraio M \& Saltin B. Searching for the exercise factor: is IL-6 a candidate? Journal of Muscle Research and Cell Motility 200324 113-119.

49 Yamamoto H \& Murphy LJ. Generation of des-(1-3) insulin-like growth factor-I in serum by an acid protease. Endocrinology 1994 $1352432-2439$.

50 Frystyk J. Free insulin-like growth factors - measurements and relationships to growth hormone secretion and glucose homeostasis. Growth Hormone and IGF Research $200414337-375$.

51 Bermon S, Ferrari P, Bernard P, Altare S \& Dolisi C. Responses of total and free insulin-like growth factor-I and insulin-like growth factor binding protein-3 after resistance exercise and training in elderly subjects. Acta Physiologica Scandinavica $199916551-56$.

52 Kanaley JA, Frystyk J, Moller N, Dall R, Chen JW, Nielsen SC, Christiansen JS, Jorgensen JO \& Flyvbjerg A. The effect of submaximal exercise on immuno- and bioassayable IGF-I activity in patients with GH-deficiency and healthy subjects. Growth Hormone and IGF Research 200515 283-290.

53 Lee PD, Durham SK, Martinez V, Vasconez O, Powell DR \& GuevaraAguirre J. Kinetics of insulin-like growth factor (IGF) and IGF-binding protein responses to a single dose of growth hormone. Journal of Clinical Endocrinology and Metabolism $1997822266-2274$.

54 Holloszy JO. Exercise-induced increase in muscle insulin sensitivity. Journal of Applied Physiology 200599 338-343.

Received 6 March 2007

Accepted 20 July 2007 